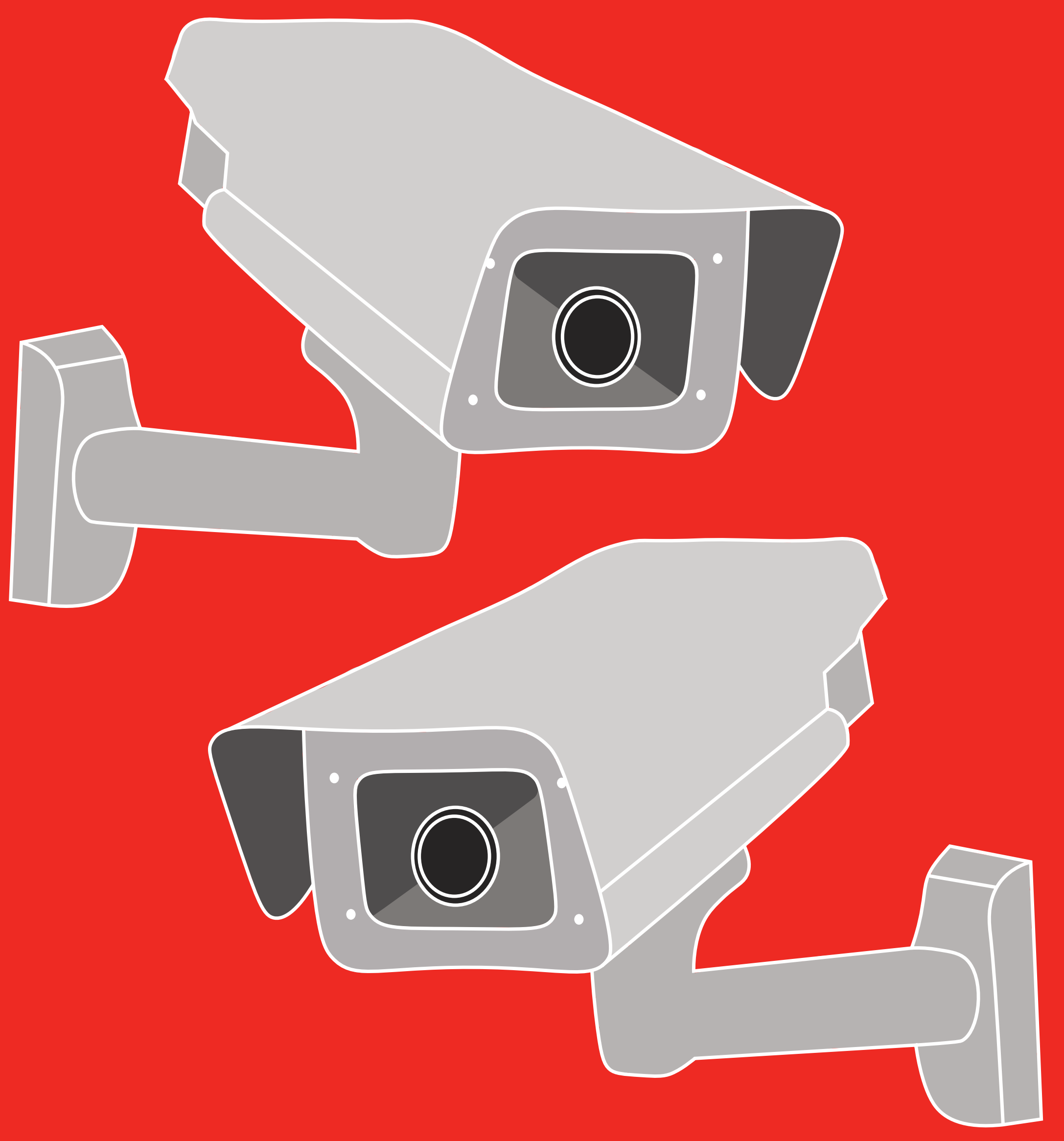

Two Birds, One Policy:

The Establishment of the National Supervisory Commission as a Factional and Centralizing Tool

Maya Mainland-Gratton, Liam Olsen, and Naomi Shi Edited by Dan Bedford Comte and Amir Hotter Yishay

ABSTRTACT - Xi Jinping has made "anti-corruption" campaigns a hallmark of his leadership. The campaigns promise to target both "tigers" - senior party, government, and military leaders - and "flies" - local party and government officials. This practice has included a drastic restructuring of China's anti-corruption and judicial agencies, culminating in their centralization under the National Supervisory Commission (NSC) in 2018. Many scholars have debated whether Xi's campaigns and the NSC are genuinely intended to combat corruption or are instead a tool to eliminate political opponents and consolidate power. The NSC's establishment is considered in relation to the two predominant models of anti-corruption drives conducted in China, the "Chongqing" model, and the "Guangzhou" model. By deliberately reproducing the Chongqing model's accountability defects, eliminating political opponents appears to be a core objective of the NSC's establishment. However, owing to its centralized nature, the NSC also strengthens the central party's power over local authorities. Local party branches are far less trusted by the population than their national counterparts. Thus, strengthening the party's credibility - including a genuine attempt to decrease corruption - and strengthening local government oversight appears to be another objective of the NSC's establishment. 
$\mathrm{n}$ the People's Republic of China, "anticorruption" has long been a prominent feature of politics that has helped sustain one-party rule. Since assuming the leadership in 2012, $\mathrm{Xi}$ Jinping has made anti-corruption even more prominent. He famously declared that his anticorruption campaign would catch both "tigers" and "flies," a euphemism for both high-ranking officials and ordinary bureaucrats (Branigan 2013). This culminated in the creation of the National Supervisory Commission (NSC) in 2018 (Li and Wang 2018, 2). Previously, a patchwork of judicial and disciplinary institutions had been responsible for anti-corruption; they reported to a range of authorities, including the very bodies they were supposed to police. The NSC consolidates this patchwork into a single disciplinary body that reports solely to the National People's Congress. While the government claims this will improve the independence and efficiency of anti-corruption campaigns, the consolidation also makes it substantially easier for Xi Jinping to target rival political factions and his political opponents (CGTN Africa 2018). Therefore, while the NSC was designed to strengthen anti-corruption efforts, it simultaneously consolidates Xi Jinping's power and strengthens the Chinese Communist Party's (CCP) control over the state, judiciary, and local government. This article begins by examining the NSC's origins; it explores the legitimate accountability problems its establishment sought to resolve and exposes its defects as an anticorruption agency. Then, it locates the NSC within Xi Jinping's anti-corruption campaigns, suggesting that it is primarily a tool of factional warfare with the Chinese Communist Party. Finally, public confidence in local governments is examined, where the NSC has emerged as a mechanism to centralize control over unpopular local authorities.

\section{The National Supervisory}

\section{Commission: The Basis of its}

Inception and its Implications

Prior to $\mathrm{Xi}$ Jinping's recent reforms,

two disciplinary agencies existed: The Central
Commission for Discipline Inspection (CCDI) and the Anti-Corruption Force of the People's Procurato Procirtion (PP) (Li and Wang 2018, supervision over the CCDI; whereas, the CCDI investigated corruption cases (especially involving senior Party officials), coordinated anti-corruption initiatives, and collected information regarding violations of Party discipline (4). The CCDI's mandate was limited to "immoral" behaviour and Party disloyalty such as having a mistress or speaking ill of the Party. While such behavior is not corrupt in a legal sense, in China it is seen as moral corruption and an indicator that the person might engage in criminal activity (7). Perhaps more significantly, it defines partisan disloyalty as a form of corruption, which stands in sharp contrast to Western conceptions of corruption. While the two institutions were often able to collaborate, the dual-track system led to competition and conflict (Li and Wang 2018,2). Moreover, the CCDI's lack of autonomy from the Party constrained its ability to investigate officials (Guo 2014, 598). The CCDI was subordinate to the Politburo of the Communist Party; in some cases, investigations could only be conducted with the latter's consent $(599,607)$. Moreover, the CCDI's local government-level branches-the Disciplinary Inspection Committees (DICs)Discip hugely reliant on the local Pary commits they were supposed to be supervising (611). Party committee leaders were able to determine the salaries, housing, benefits, and retirement packages of DIC officials (611). This relationship created a fatal conflict of interest for DIC officials. investigating party committees, DIC officials often chose to defend or cover up the improper activity of their party committees in exchange for benefits. In 2004, this flaw was recognized and the DICs were brought "under a vertical chain of command" where they reported solely to the DIC level superior to

In practice, DICs, especially at prefecture and county levels, lacked resources and its personnel lacked legal training and academic qualifications to conduct investigations. This often led them to collaborate with the People's
Protectorate, who would provide experience and advice on legal and evidential issues ( $\mathrm{Li}$ and Wang 2018, 6). However, the overlap between the two institutions often led to competition. For example, the PP was "ranked and rewarded" by the number of cases investigated, docketed, and prosecuted, as well as the withdrawal rate, prosecution rate, and conviction rate, and the most highly ranked officials were rewarded both through monetary and non-monetary means, including promotion (10). Additionally, when both agencies did investigate the same case, there was only an informal tradition for allocating responsibility, namely, that the institution that spent the most time and effort and achieved the most progress kept the case; this lack of adjudication worsened competition. According to Li and Wang (2018), interactions between these two mechanisms created conflict over resources as the CCDI would want to borrow personne from the PP, who protested as they had their own cases to investigate (11). Moreover, both agencies blamed the other when investigations went awry, weakening the accountability of both organizations.

Recognizing the difficulties of this dual-track system, the CCP established a new supervisory system, rolling out Supervisory Committees (SCs) in Beijing, Shanxi, and Zhejiang provinces in 2016 (Deng 2018, 59). In 2018, the CCP went a step further and created the National Supervisory Commission (NSC), which integrated the former two systems (Li and Wang 2018, 14). This transformed the former disciplinary system "into a single anti-corruption agency system"; SCs now exist at provincial and county levels, with the NSC at the top (Deng 2018, 59). By combining the dual-track system under one overarching disciplinary body, the Party aims to eliminate the conflict between the two former systems. However, the National Supervisory Commission comes with its own challenges; it enhances the political control of the CCP's central leadership, as the People's Procuratorate has been absorbed into the Disciplinary Inspection Committees, and the DIC system is continuing under the NSC (Deng 2018, 69, 70). The CCDI played a key role in drafting the National Supervision Law, which places China's ongoing anti-corruption campaign under legal procedures, expanding its powers of investigation while reducing the authority of other agencies. Consequently, the CCP now exercises significant influence on the operation of the criminal justice system, weakening the independence and capacities of the courts and the People's Procuratorate, potentially making the process of prosecution and trial unjust (Li and Wang 2018, 17). The creation of a solitary disciplinar the NSC, raising issues about who will supervise the NSC itself. The Party instead emphasizes internal supervisory mechanisms, including "the separation of case investigations and case resolutions, the establishment of a self-supervision department, and the issuance of Party rules regulating the SCs' behaviors" (Deng 2018, 70).

Lastly, a controversial feature of the new law is that it grants the NSC the legal power to detain suspected bribe givers and seekers for three to six months. This not only violates human rights but also potentially harms the local economy by creating a risk-averse culture within the public service, as individuals would be more reluctant to push boundaries out of fear of being accused of bribery and suffering consequent persecution. The National Supervision Law also increases the CCP's ability to control corruption by removing public officials' constitutional rights, including their access to lawyers ( $\mathrm{Li}$ and Wang 2018, 19,20). The extremity of the NSC's power to oversee the operation of the local government may also weaken local government authority and ironically create new conditions for corrupt behaviour (18). Xi Jinping's reforms are duplicitous; under the auspices of an anti-corruption agenda, he has consolidated his power and that of the CCP, while weakening human rights protections and the rule of law.

\section{Anti-Corruption as a Mechanism of}

\section{Factional Conflict}

On the surface, Xi Jinping's reforms are designed to address the rampant corruption in China; however, there is evidence that the underlying motivation may be to target his opponents in rival political factions. Scholars 
Jiangnan Zhu and Dong Zhang (2016) believe that political leaders often politicize corruption and use anti-corruption campaigns to target their political enemies, theorizing that the crackdowns on corruption and prosecutions of corrupt officials tend to be factionally biased and arbitrary in an authoritarian country like China (1187). The prevalence of factional division in Chinese politics suggests that the anti-corruption campaign is a means through which Xi Jinping can weaken or eliminate his political rivals. By extension, the NSC functions as a mechanism established and utilized by $\mathrm{Xi}$ to wage factional war.

While power officially resides within the CCP under the one-party system, this does not prevent power conflicts within the Party. Communist collective leadership is undermined by Communist collective leadership is undermined by
the presence of power factions within the Party, with the rise of two coalitions that take turns occupying top central leadership positions - the elitist faction to which Xi Jinping and Jiang Zemin belong and the populist faction of $\mathrm{Hu}$ Jintao and Li Keqiang (Li 2016, 249-251). For example, General Secretary of the CCP underwent such a rotation, with the elitist Jiang Zemin succeeded by the populist $\mathrm{Hu}$ Jintao, who has now been replaced by the elitist Xi Jinping. Prior to Xi, the division of top leadership positions between the

was near-perfectly balanced (253) When $\mathrm{Xi}$ assumed leadership, he consolidated his power, reducing the strength of his opposing faction and ending the powersharing that characterized the regimes of his predecessors. Forty-eight tigers' were prosecuted by Xi's anti-corruption campaign, almost all of whom were associated with the populist camp, including former Politburo Standing Committee members, Zhou Yongkang and $\mathrm{Xu}$ Caihou. While some of the elitists were also removed from their positions and faced sentencing, most received milder punishments compared to the prosecuted populist camp members, who faced more severe verdicts, including the death sentence ("Corrupt Bureaucrats and Bloodlines"). Thus, the NSC, as an overarching disciplinary body without clear external checks, serves as a new and improved weapon to continue factional warfare.
In China, two general models of anticorruption have been studied and compared: the Chongqing mod aggressive, centralized, top-down policing, and the Guangzhou model, which relies on introducing financial transparency in the government, allowing citizens to report corruption. The latter has been more effective, as the proportion of misused funds in Guangzhou declined from approximately 28

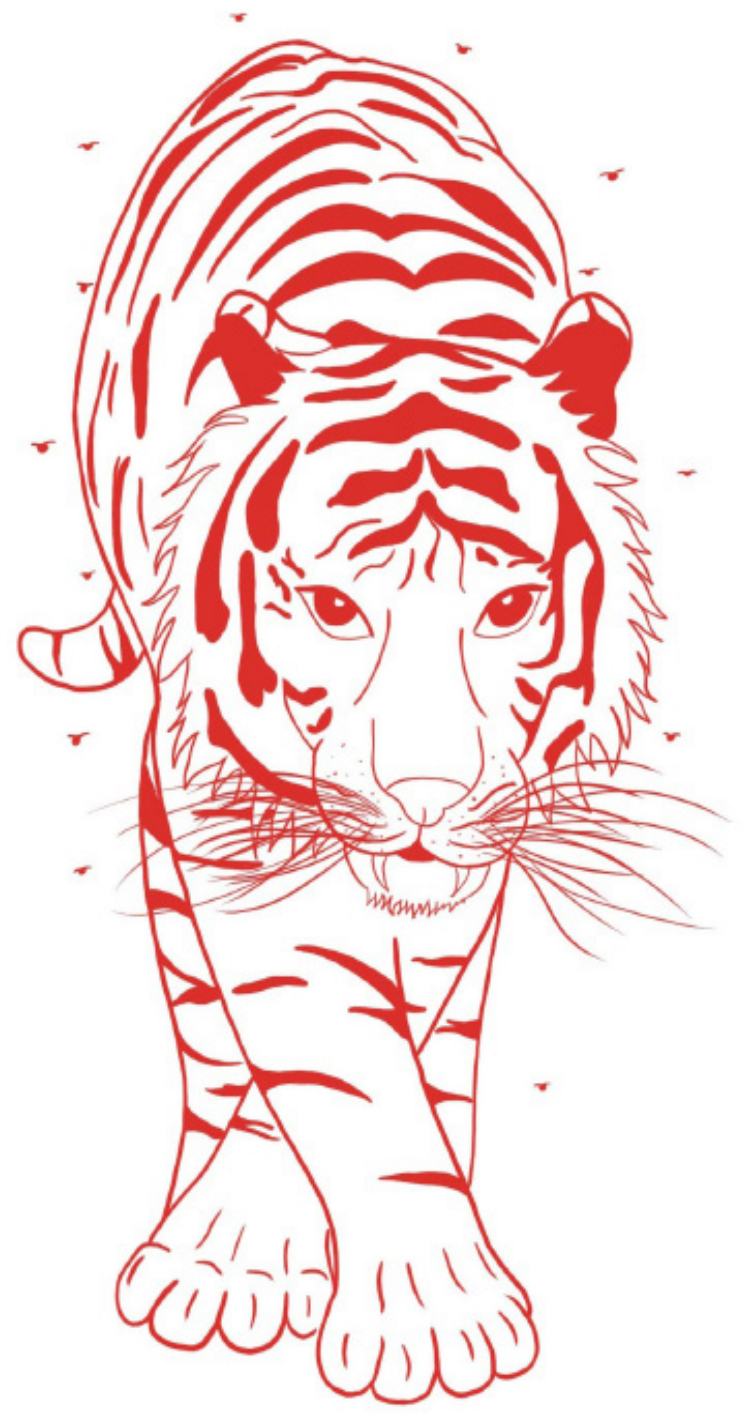

per cent to 2 per cent after the implementation of the policy, whereas in Chongqing it increased from approximately 7 per cent to 11 per cent. If the central leadership was solely concerned with combating corruption, the Guangzhou model would have been adopted. Instead, the NSC more closely resembles the Chongqing model, as the NSC strengthens Party oversight of its officials without external checks on its power (Stromseth et al. 2017, 108). The same problems that befell the Chongqing model-namely, that the monopolization of investigative power over officials by the police led to the politicization of the entire system, and ultimately more corruptionare at risk to the NSC, which has consolidated the Party's power, with Xi Jinping at its head.

\section{The Depth and Pervasiveness of \\ Corruption in China}

While anti-corruption mechanisms can be seen as political tools that serve to purge $\mathrm{Xi}$ Jinping's rivals, corruption remains a substantial issue in the Chinese state. In 2016, 83 per cent of the Chinese population believed corrupt officials were a significant issue in Chinese politics, topping the list of all other public concerns ("Corrupt Officials are Top Chinese Concern" 2016). Additionally, political corruption has worsened since the introduction of the market reforms in the 1980s. The characteristics of corruption were significantly reshaped and expanded as a result of the decentralization and increased autonomy of the economy under the reforms led by Deng Xiaoping. In addition to systemic corruption, which commonly sources of exploitation arose, driving harsher forms of profiteering, squandering, negligence, and privilege seeking (Sun 2018,51). Officials no longer need to have physical control of public resources to seek private gain. Instead, corruption is more likely to emerge with officials who have regulatory and allocative powers such as decision-making powers over matters like credits, trade, contracts, land, and privatization (52). Despite the inherent weaknesses in the anti-corruption campaign noted above, the establishment of the NSC remains, at least in part, a genuine attempt to address public concern with systemic corruption in China.

Xiaobo Lu depicts corruption as consisting not of multiple cases of individual misconduct, but as a part of a larger official deviance from organizational norms. Referring to this phenomenon as "organizational involution," he characterizes the Party's evolving inability to maintain transparent and committed officials at different levels of government as a result of "the party's new i failure to meet the challenges of post revolution routinization" (Sun 2001, 847). Consequently, traditional patterns of behaviour, such as parochial loyalty, personal networks, and kinship ties are reinforced. Lu's characterization of corruption as a prevalent organizational norm coupled with the mounting public concern about it suggests that the previous disciplinary bodies targeted to curb corruption, namely the CCDI and PP, had been ineffective in eradicating corruption. Xi's new anticorruption reforms, sweeping as they are, cannot be dismissed as solely designed to support his efforts to consolidate his power; Xi has to be seen as making an earnest attempt at anti-corruption. Additionally, Lu's understanding of corruption to be inherent in all levels of government also explains why over 70 per cent of purges occurred at the local (township and village) level ("Visualizing China's AntiCorruption Campaign" 2018). This challenges the Cactional argut factiona anply to Party's (and Xi's) grip on the central government.
Palinate high-level officials and strengthen the

\section{The NSC as a Factional and}

\section{Centralizing Too}

On balance, it appears that the NSC has multiple objectives that are often in conflict with one another; this is ironically illustrated by Cheng $\mathrm{Li}$ in his defense of the anti-corruption campaign's legitimacy. Li argues that the appointment of Wang Qishan as the head of the CCDI in 2013 is evidence of the meritocratic, non-factional nature of the policy given Wang's reputation as a "respected, competent leader" (US-China Policy Foundation 2014). However, Wang, who was trained as an economic planner, had zero experience in anticorruption before his appointment ( $\mathrm{Li} 2018$, 1). While Wang had become popular due to his successful execution of the 2008 Beijing Summer Olympics, his popularity was not unique among Chinese leaders and alone does not justify his rise from a meritocratic perspective $(1,2)$. What is unique is Wang's close relationship with Xi Jinping, 
which dates back to the Cultural Revolution, when they were roommates (1). Wang's appointment is thus, far more consistent with appointing a staunch loyalist to carry out a political purge than that of a highly qualified official heading a politically neutral, investigative body. Yet again, factionalist motivations and cronyismdonotinand of themselves negate an anti-corruption agenda - officials may fficial's corruption used as justification for a purge.

Rather than being mutually exclusive visions of the NSC's purpose, the factional warfare argument and the argument illuminating a genuine concern with corruption in China appear to describe different levels of the NSC's operations. At the "tiger" level, the NSC plays an inherently factional role, centralizing investigative and prosecutive authority more directly under the President and his allies' control. At the "fly" level, the NSC serves to lend the Party a cloak of legitimacy and shore up the central leadership's credibility with the public.

The difficulty in obtaining the cooperation of local government is often overlooked or completely underestimated. As Yi-Chong and Weller (2016) note, "the Premier has to persuade ministers and governors of provinces, regions, and municipalities to cooperate" (9). In one notable outburst, Premier Zhu, who served under Jiang Zemin, complained that "low-level bureaucrats decided to ignore all instructions, regardless of whom they are from" (10). Given the broad centralizing thrusts undertaken by Xi, it is reasonable to expect he would also attempt to consolidate power over local governments.

Western scholars often overlook the fact that corruption is not a clear, legally defined concept in China as it is in most Western countries. The acceptance of illegal gratuities, for example, is not criminalized; instead, anti-corruption is defined merely as the acceptance or gift of "property from others" (Deng 2018, 68). This definition is not only vague, it also overlooks other significant benefits beyond the scope of criminal corruption, including career advancement and sexual favours; moreover, conflict of interest laws do not exist. While antibribery guidelines exist, these have been weakened rather than strengthened over time. Before 1997 , the Supreme People's Court suggested a "gift" of 5000 RMB should constitute a criminal offense. which is the equivalent of over CA\$5,600. The 1997 criminal law reform regarding bribery replaced numbered amounts with the categories "relatively large," "huge," and "extremely huge" (68). With corruption ill-defined in China, anticorruption policies and agencies are similarly illdefined. This leaves open the possibility for what Deng terms "leading control," which is the concept that "party leadership in anti-corruption efforts is legitimate under China's legal framework, as China's constitution upholds the party's leadership in every aspect of the country's governance" (Deng (D) than in the West, in that it may refer to a more general installation of moral authority. Anticorruption could therefore be conceived of as a tool for extending the morally superior influence of the central leadership into local governance. By centralizing power over townships and villages, the $\mathrm{CCP}$ overcomes their as well as the public's distrust of local-level governance. According to data collected in the Asian Barometer Survey, the Chinese population trusts the local government (68 per cent) far less than the central government (96 per cent) (Wu and Wilkes 2017 440). When the Party attempts to respond to popular opinion by enacting environmental reforms or anticorruption efforts, there is evidence to suggest the local government thwarts such reforms, which gives the Party a bad name. For example, the case of Yang Dacai, also known as "Brother Watch," is an archetypal case of local officials blatantly living beyond what is financially possible for their pay bracket. Brother Watch became famous for wearing at least eleven luxury watches valued between US $\$ 3,000$ and US $\$ 12,000$, each on a salary of less than US\$1,000 per month (Zhai 2013). However, this is not an isolated case and local government stealing central government funding and this may be severe enough to threaten the implementation of the central government's policies. In 2014, one village in the Anhui province reported that 100 per cent of money earmarked for pension funds was stolen by village officials, with about 20 per cent of the money instead spent on gambling (Mai 2017). Thus, deepening the center's control over anti-corruption and local government decision-making may genuinely lead to improved perceptions of the Chinese government and improved governance at the local level.

\section{Conclusion}

The establishment of the NSC and the anti-corruption policy as a whole, cannot be compartmentalized to fulfill a single outcome. The factional argument advanced by many scholars and Western media explains much of the pattern of anti-corruption arrests and punishments observed at the "tiger" level but does not account for the policy's ramifications at the "fly" level. Moreover, the factional argument does not acknowledge the threat posed by corruption to an increasingly fragile economy, the ability of the central government to implement policy, and the CCP's legitimacy. However, the anti-corruption policy is not without ulterior motives, as it is undermined by the correlation between arrests and factional affiliation, and as the NSC grants the Party sole control over disciplinary procedures. In sum, the creation of the NSC reflects the "multi-layered cake of motivations" of anti-corruption policy in China; it strengthens Xi's factional power over rival "tigers" and the Central leadership's hold over local government "flies" (Center for Strategic and International Studies 2016). As Stromseth et al. (2017) state, "China's history can be seen as a long, cyclical struggle to rule such a vast kingdom [...] the most important job of all for the state was to control local officials" (33). As both rival factions and insubordinate or corrupt local officials threaten Xi and the central leadership's ability to rule China, the establishment of the NSC and the broader anti-corruption policy were driven by both factional and anticorruption imperatives.

\section{References}

Branigan, Tania. 2013. "Xi Jinping Vows to Fight 'Tigers' and 'Flies' in Anti-Corruption Drive.” The Guardian . January 22, 2013. www.theguardian.com/world/2013/jan/22/xijinping-tigers-flies-corruption.

CGTN Africa, 2018. China: How A National Su pervisory Commission Can Make A Difference. [video] <https://www.youtube.com/ watch? $v=5$ Nc6fGBTAXs $>$.

Center for Strategic \& International Studies, 2016. Christopher K. Johnson: Can X Jinping's Anti-Corruption Campaign Succeed? [video] <https://youtu.be/0USIKN0mqo0>. "Corrupt Bureaucrats and Bloodlines: Commoner-officials Fall to Earth, the Red Second Generation is Untainted? 贪 官与血 统：平民官落马红二代不贪 ? ”, Voice of America, 9 October 2014. http://www. voachinese.com/content/few-red-princeingstargeted-in-anti-corruption-camp agin-20140910/2444657.htm 1.

"Corrupt Officials Are Top Chinese Concern." Pew Research Center's Global Attitudes Project ,Pew Research Center, 4 Oct. 2016. https://www.pewresearch.org/

global/2016/10/05/chinese-public-sees-morepowerful-role-in-world-names-u-s-as-topthreat/10-4-2016-9-39-43-am/.

Deng, Jinting. 2018. “The National Supervision Commission: A New Anti-Corruption Model in China." International Journal of Law, Crime and Justice 52: 58-73. doi: 10.1016/j. ijlcj.2017.09.005.

Guo, Xuezhi. 2014. "Controlling Corruption in the Part: China's Central Discipline Inspection Commission.” The China Quarterly 219: 597-624

Li, Cheng. 2016. "Chinese Politics in the Xi Jinping Era: Reassessing Collective Leadership."Brookings Institution Press Li, Cheng. 2018. "Wang Qishan 王岐山 .” Brookings Institution

Li, Li, and Peng Wang. 2018. "From Institutiona Interaction to Institutional Integration: The National Supervisory Commission and China's 
FLUX: International Relations Review

New Anti-Corruption Model.” The China

Quarterly 240: 1-23. doi:10.1017

S0305741019000596.

Lu, Xiaobo. 2002. "Cadres and Corruption: The

Organizational Involution of the Chinese

Communist Party.” Stanford University

Press . ProQuest Ebook Central . https://

ebookcentral.proquest.com/lib/mcgill/detail.

action?docID=3037476.

Mai, Jun. 2017. "Corrupt Officials Hold Back Chi na's Drive to Eliminate Poverty." South China Morning Post . August 29, 2017. https://

www.scmp.com/news/china/policies-politics/ article/2108613/corrupt-officials-holding-backchinas-drive-eliminate.

Stromseth, Jonathan R., et al. 2017. China's Gover nance Puzzle: Enabling Transparency and Participation in a Single-Party State

Cambridge University Press.

Sun, Yan. 2018. "Corruption and Market in Contemporary China ." Cornell University Press

Project MUSE muse.jhu.edu/book/59901.

Sun, Yan. 2001. "Corruption in Its Context." The Review of Politics 63, no. 4: 847-849.

www.jstor.org/stable/1408875.

US-China Policy Foundation, 2014. China Forum \#93: President Xi Jinping's Anti-Corruption Campaign. [video] $<$ https://youtu.be/

VUcAqJRdRSY>

"Visualizing China's Anti-Corruption Campaign." China File . August 15, 2018.

www.chinafile.com/infographics/visualizingchinas-anti-corruption-campaign? fbclid=Iw. 